DOI: 10.37943/AITU.2020.73.19.008

\title{
D. Tymchenko
}

Teacher of the Department of Intellectual Property and Projects Management dariatymchenko1@gmail.com, orcid.org/0000-0003-2784-883X National Metallurgical Academy of Ukraine, Ukraine

\section{N. Korogod}

Candidate of Pedagogical Sciences, Associate Professor, Head of the Department of Intellectual Property and Projects Management nkorogod@gmail.com, orcid.org/0000-0002-0242-549 National Metallurgical Academy of Ukraine, Ukraine

\section{T. Novorodovska}

Candidate of Biological Sciences, Associate Professor, Associate Professor of the Department of Intellectual Property and Projects Management tetiana.novo@gmail.com,orcid.org/0000-0002-4654-843X National Metallurgical Academy of Ukraine, Ukraine

\section{TECHNOLOGY TRANSFER OFFICE MODEL}

\begin{abstract}
At present creation of specialized organizational structure, the technology transfer office (TTO) in higher education institutions (HEIs) becomes increasingly important for establishing communication between scientists, business, and the state and for implementation of the results of scientific and technical activities of higher education institutions in the real sector of the economy. Surveys of domestic and foreign scientists show that the issues of creating project offices (which in fact are TTOs) in HEls remain insufficiently explored. Given this, the authors conducted a study of project management to create a TTO in a HEl. Efficient organizational project management requires the presence of Organizational Breakdown Structure. This article proposes an Organizational Breakdown Structure template, which clearly demonstrates the project team structure targeted at TTO creation in a HEI, the subordination and basic functions of each team member. In addition, the article proposes a model of organizational structure of the newly created TTO, which is also a template for HEI, and which defines the structure of the office staff, their subordination and main functions. To determine the location of the TTO in the structure of HEI, the article proposes a corresponding model that shows the subordination and connection of the office with other functional units of HEI. Using the models presented in the article, any HEI will be able to effectively manage the project of creating a TTO and as a result to create a project product - a TTO.

Key words: technology transfer, technology transfer office, technology transfer office model.

\section{Introduction}

Every year in higher education institutions (HEIs) of Ukraine innovative technologies are created but the most of them remain unimplemented [1]. Creation of the innovative ecosystem in our country becomes a priority given the direction of state policy [2].

Analysis of international experience showed that in the United States, one of the most successful countries with regard to efficiency of technology transfer (TT), the technology transfer offices (TTOs) created in HEls play an important role [3].
\end{abstract}


Domestic scientists conduct a number of studies and substantiate the formation of specialized structural units in HEls to manage TT [4; 5], but they do not use the project approach for that.

In fact, TTO is a specific organizational structure within a single information and communication system of the institution, which uses the project approach to manage projects and portfolios of TT projects.

By TT project, we mean a sequence of managing measures, which provide coordination of human, material and information resources throughout the technology lifecycle by applying project management (PM) methodology to transfer and implement the results of scientific and technological research and development of HEls in the real sector of the economy and to create innovative products based on them.

Given the above, the problem of the project approach-based creation of TTO is topical and yet unresolved. Available international standards for PM $[6 ; 7 ; 8]$ provide only definitions and type classification of the project offices, whereas insufficient attention is payed to organization of such offices.

Foreign and domestic scientists also do not sufficiently cover the issue of creating project offices. Domestic scientists [9; 10] develop the concept of project office and define its functions, features and types. The author [11] described the operation features of project offices, their types, benefits and main stages of creation. The author [12] proposed an algorithm of creation and a conceptual model of the project office in the company.

However, the issue of organization of project offices in HEls has specific its own features, and therefore requires more in-depth research [13].

We used a systematic approach and method of constructing hierarchical diagrams in this study that is based on the concept of the triple helix [14], which provides for the interaction of HEl, government and business [6].

\section{Main structure}

An effective project implementation depends primarily on clear division of tasks between specific executors or units. Subordination in the project team is presented in the form of organizational breakdown structure (OBS) of the project of TTO creation, the template for HEI of which is given by the author on fig. 1 .

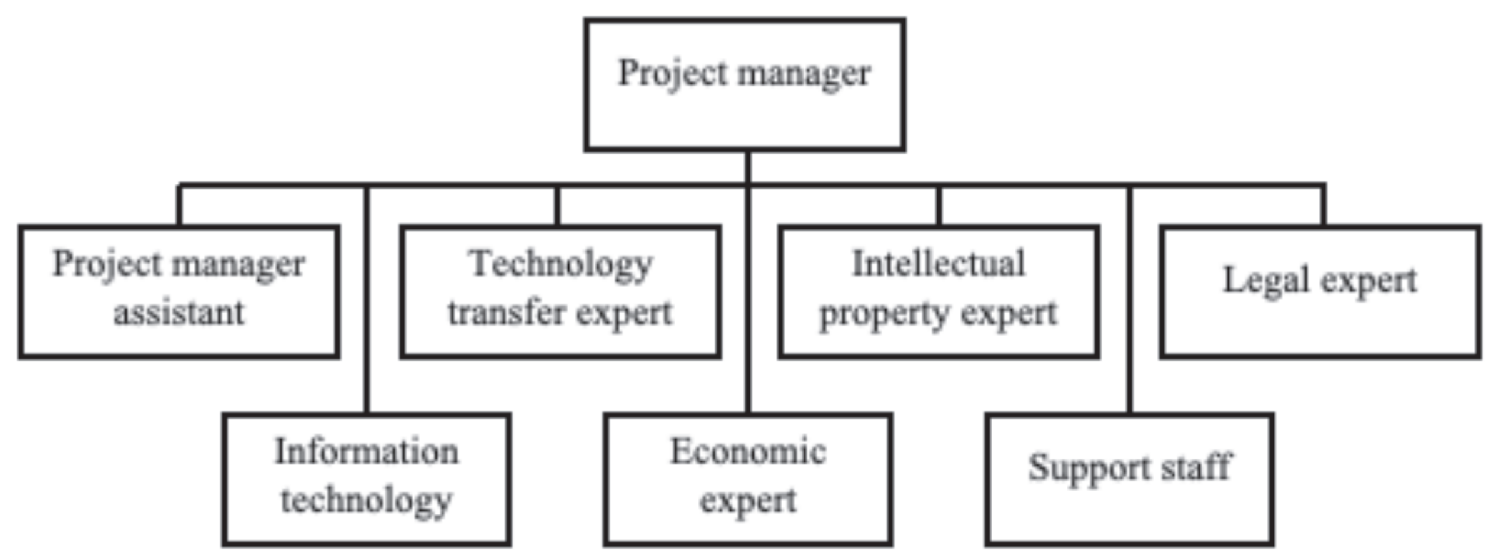

Fig. 1. The template of OBS of the project of TTO creation in HEI

The distribution of functions and tasks of the team members of the project of TTO creation in $\mathrm{HEl}$ is presented in table 1. 
Table 1. Functions of the team members of the project of TTO creation in HEI

\begin{tabular}{|c|c|}
\hline Team member & Main functions \\
\hline Project manager & $\begin{array}{l}\text { Provides general PM, approval of the charter, basic project plan, OBS project, } \\
\text { organizational structure of TTO, IP policy, sets criteria for project team selection, selects } \\
\text { the project team, TTO staff, makes communication between project team members, } \\
\text { stakeholders, conducts project implementation monitoring }\end{array}$ \\
\hline $\begin{array}{l}\text { Project manager } \\
\text { assistant }\end{array}$ & $\begin{array}{l}\text { Develops the project's charter, basic project plan, OBS project, organizational structure of } \\
\text { TTO, conducts trainings on PM, implements the PM methodology into work }\end{array}$ \\
\hline TT expert & $\begin{array}{l}\text { Advises on all issues related to TT, determines the requirements for TTO specialists, their } \\
\text { functions, determines the criteria for selection to TTO, organizes the selection, creates a } \\
\text { standard form of technology description to file information about it in technology and IP } \\
\text { rights sections of HEl's site }\end{array}$ \\
\hline IP expert & $\begin{array}{l}\text { Develops IP policy, forms that HEl's employee should fill in when creating technology, } \\
\text { defines criteria for deciding on the expediency of registering technology as IP right } \\
\text { object (hereinafter - IPRO), monitors the existing and potential IPRO in HEI, makes } \\
\text { analysis of information on technologies and IPRO of HEI, makes reports based on } \\
\text { obtained information, develops database architecture of IPRO in HEI }\end{array}$ \\
\hline Legal expert & $\begin{array}{l}\text { Provides documentation of the project, preparation or preliminary coordination of } \\
\text { contracts with contractors or suppliers, IP policy }\end{array}$ \\
\hline IT expert & $\begin{array}{l}\text { Creates virtual communication channels for the project team, develops architecture } \\
\text { and selects software for TTO operation, searches for developers, implements cloud } \\
\text { technologies, develops IPROs database, technology section of the website }\end{array}$ \\
\hline Economic expert & Prepares documentation on the project budget, makes planning, cost monitoring \\
\hline Support staff & Arranges rooms for the project team, TTO \\
\hline
\end{tabular}

A project manager of TTO creation in HEI could be an employee of HEl (head of department, professor or associate professor) who is responsible for project planning and implementation, risk response, provides communication between the project team members, sets up the project team for fruitful work, approves documents and communicates with project stakeholders. Requirements to be met by the project manager:

skills in PM methodology and experience in applying PM models and methods in practice; close ties with senior management and heads of functional units of $\mathrm{HEl}$;

communication skills and skills to create a psychological climate acceptable for the introduction of changes in $\mathrm{HEl}$;

knowledge in the field of IP and TT.

A project manager assistant implements the PM methodology in the work of the project team and TTO, organizes PM trainings to heighten the level of knowledge of functional managers of HEls, develops the charter, basic project plan, develops OBS of TTO project in HEI, organizational structure of TTO. The project manager assistant could be an employee of HEI, who professionally carries out scientific, scientific and technical or scientific and pedagogical activity and has skills on the PM methodology.

A TT expert advises on all issues related to TT, determines the requirements for TTO specialists, their functions and powers, organizes the selection. An expert in TT could be a HEI employee who professionally carries out scientific, scientific and technical or scientific and pedagogical activities, has education and experience in the field of IP, has been trained in TT and has skills in this field.

An IP expert develops the IP policy of HEI, template documents (forms) to be filled in by $\mathrm{HEI}$ employee in case of technology creation, determines the criteria for deciding on the 
expediency of registering the technology as IPRO, audits existing and potential IPRO in HEI, collects information obtained and files it into a single database, the structure of which is determined together with an IT expert, analyzes the number of implemented IPROs in relation to the number of registered and in relation to the number of created ones. An IP expert could be HEl's employee who professionally carries out scientific, scientific and technical or scientific and pedagogical activities, has education and experience in the field of IP.

A legal expert provides documentation of the project subject to amendments to the chart of the $\mathrm{HEI}$, develops the regulations on a structural unit, job descriptions and other documents required for TTO creation, as well as preparation or approval of contracts with suppliers and/ or contractors, IP policy of HEl. A legal expert could be an employee of HEI who professionally carries out scientific, scientific and technical or scientific and pedagogical activities, has legal education and experience in the field of jurisprudence.

An IT expert organizes the creation of virtual communication channels, selects software for the project team and TTO or develops the architecture of the future program, searches for developers, monitors contractors' performance of tasks, installs selected software, assists the team on its mastering and mastering of cloud technologies, which are subject to implementation, develops the architecture of the database of technologies and IPROs of HEls, ensures the creation (search for developers) and operation of the technologies and IPROs section of HEI website, analyzes the channels of website promotion. An IT expert could be a $\mathrm{HEI}$ employee who professionally carries out scientific, scientific and technical or scientific and pedagogical activities, has education and experience in the field of IT and programming.

An economic expert prepares documentation on the project budget, makes planning and monitoring of costs. An economic expert could be a HEl employee who professionally carries out scientific, scientific and technical or scientific and pedagogical activities, as well as an accountant who has education and experience in the field of economics or accounting.

In the absence of any of the mentioned experts in $\mathrm{HEl}$, it is possible to involve him/her from third-party organizations or to teach him/her these skills. Also, in the case of a combination of knowledge and skills in one of the employees, for example, in the field of IP and in the legal field, both roles (IP expert and legal expert) could be performed by one person.

The support staff arranges rooms for the project team, TTO, makes reparation works if necessary, brings furniture, equipment, etc. Support staff includes two technicians who may have a secondary special education and perform only technical functions.

Project team members work closely with each other to implement the project effectively. The interaction is organized by the project manager and his assistant. When selecting a project team, the manager should take into account the above-mentioned skills, experience, education, as well as the character and communication skills of a candidate. For effective work, the project team must be a single whole, pursue a common goal and respond quickly to risks.

Under the condition of effective project implementation, as a result of its completion, the project product - TTO will be created. In addition, another product of the project will be a newly created section on HEI website, dedicated to technologies, developments and IPROs of HEl.

In order to clearly understand the subordination and number of employees in TTO, as well as to distribute the functions and tasks of such employees, we offer a template of the organizational structure of TTO in HEl as shown in fig. 2. 


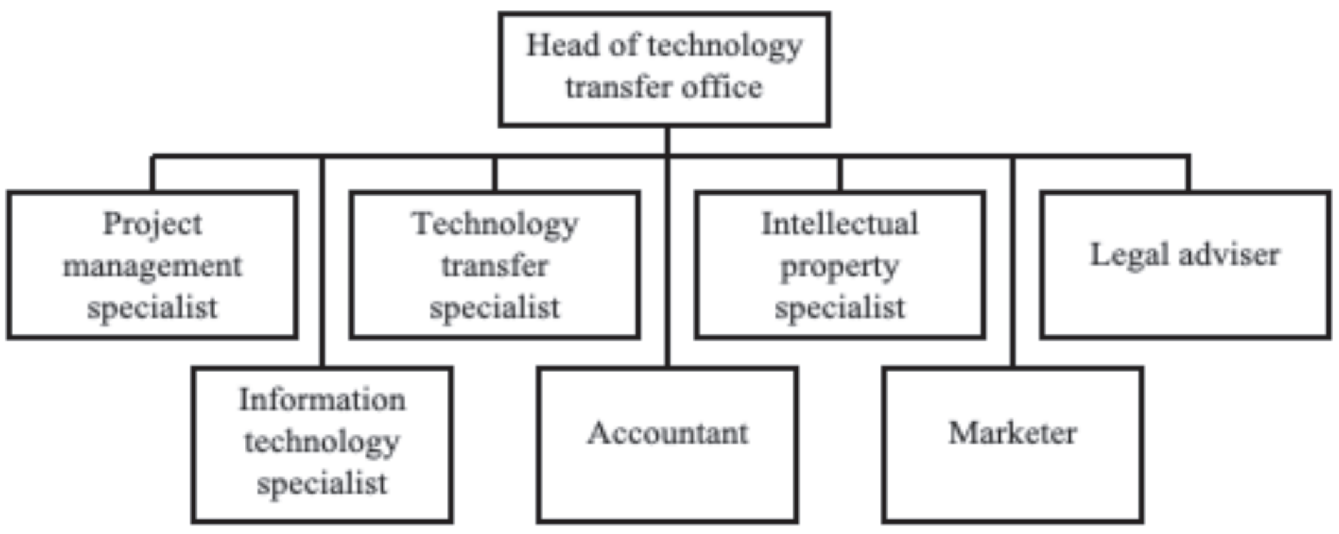

Fig. 2. A template of the organizational structure of TTO in HEI

Functions of above-mentioned TTO's employees are shown in table 2.

Table 2. TTO employees' functions

\begin{tabular}{|c|c|}
\hline TTO's employee & Main functions \\
\hline Head of TTO & $\begin{array}{l}\text { General management of TTO, approval of documents, provision of communications } \\
\text { between TTO employees, senior management of HEI, potential consumers and other } \\
\text { stakeholders, raising questions about the future of the technology (whether it should be } \\
\text { registered, promoted etc.) based on the description provided by the TT specialist subject } \\
\text { to discussion for decision-making by the Academic Council, after a positive decision } \\
\text { by the Academic Council transmits the relevant information to the IP specialist for } \\
\text { IPRO registration and to the IT specialist to input the description of the newly created } \\
\text { technology in the site section dedicated to technologies and IPRO of HEI }\end{array}$ \\
\hline PM specialist & $\begin{array}{l}\text { Implements the PM methodology in the work of TTO, provides training in models and } \\
\text { methods of PM, studies TTO projects, forms the knowledge base of TT projects, helps with } \\
\text { the implementation of TT projects }\end{array}$ \\
\hline TT specialist & $\begin{array}{l}\text { Advises on all issues related to TT, implements TT projects, searches for potential } \\
\text { consumers of HEl's technologies and international partners, assists innovators to file the } \\
\text { documents (description of technology, applications for competitions, grants, etc.), approves } \\
\text { documents filled in by innovators }\end{array}$ \\
\hline IP specialist & $\begin{array}{l}\text { Identifies potential IPROs, develops a strategy for acquiring legal protection for IPRO, } \\
\text { transmits information to a TT specialist, registers IPRO in accordance with the strategy } \\
\text { agreed by the Academic Council, inputs IPRO in the database, orders assessment of IPRO }\end{array}$ \\
\hline Legal adviser & $\begin{array}{l}\text { Provides legal support for all stages of TT projects, prepares or approves TT agreements, } \\
\text { represents HEl's interests in disputes over IPRO and TT }\end{array}$ \\
\hline IT specialist & $\begin{array}{l}\text { Supervises the work of virtual communication channels, software, databases, website, } \\
\text { inputs information about newly created technologies and updates information in the } \\
\text { website's section dedicated to technologies and developments of HEl, promotes the } \\
\text { website on the Internet }\end{array}$ \\
\hline Accountant & $\begin{array}{l}\text { Puts IPRO on the balance according to the conducted assessment, controls money } \\
\text { transfers under TT agreements and their distribution }\end{array}$ \\
\hline Marketer & $\begin{array}{l}\text { Conducts research to identify market needs in certain technologies, monitors conferences, } \\
\text { exhibitions where HEl's technologies could be presented to potential consumers }\end{array}$ \\
\hline
\end{tabular}


with heads of functional units of $\mathrm{HEI}$, the top management of $\mathrm{HEI}$, Academic Council, potential consumers of technologies (representatives of real sector of economy) other stakeholders, is responsible for managing TT projects. The head of TTO could be an employee of HEI - vicerector or head of the department, or professor/associate professor of the department. The head of the TTO should have the methodology of PM and experience in applying models and methods of PM in practice; should have close ties with senior management and heads of functional units of the HEl; be sociable; have knowledge in the fields of IP and TT.

The PM specialist implements the PM methodology in the work of TTO, teaches PM models and methods, studies TTO projects, forms the knowledge base of TT projects, helps with the implementation of TT projects, analyzes the work of TTO, identifies systemic shortcomings, develops methods to eliminate them. A PM specialist could be an employee of the HEI, who professionally carries out scientific, scientific and technical or scientific and pedagogical activities and is aware of PM methodology.

A TT specialist advises on all TT issues, carries out TT projects, searches for potential consumers of HEl's technologies and international partners, assists innovators in creating a description of the technology and approves the information about the technology to be placed in the relevant site section of $\mathrm{HEI}$, submits the agreed description for consideration to the head. A TT specialist could be an employee of HEI who professionally carries out scientific, scientific and technical or scientific and pedagogical activities, has education and experience in the field of IP, has been trained in TT and has skills in this field.

An IP specialist identifies potential IPROs, prepares their descriptions subject to discussion in order to decide on the registration of IPROs or the impossibility of such registration by the Academic Council, prepares and submits a set of documents required for registration of IPROs, inputs information about IPROs in the database, orders assessment of IPRO. An IP specialist could be an employee of HEI who professionally carries out scientific, scientific and technical or scientific and pedagogical activities, has education and experience in the field of IP.

A legal adviser provides legal support for all stages of TT projects, prepares or approves TT agreements, represents the interests of HEI in disputes over IPRO and TT. A legal adviser could be an employee of HEl who professionally carries out scientific, scientific and technical or scientific and pedagogical activities, has legal education and experience in the field of jurisprudence.

An IT specialist supervises the work of virtual communication channels, software, databases, website, updates the information in the website section dedicated to technologies and developments of $\mathrm{HEl}$, selects channels for promotion and website promotion on the Internet. An IT specialist could be an employee of HEI who professionally carries out scientific, scientific and technical or scientific and pedagogical activities, has education and experience in the field of IT and programming.

An accountant puts IPRO to the balance in accordance with the assessment, monitors money transfers under agreements on TT and their distribution, transmits the relevant information to the head of TTO. An accountant could be a staff member of HEl.

A marketer conducts research to identify market needs for certain technologies, transmits the revealed information to the head of TTO, monitors conferences, exhibitions, where HEl's technologies could be presented to potential consumers, selects channels for promoting HEl's technologies, promotes HEl's technologies in social networks and so on.

In order to effectively implement TT projects, TTO employees should cooperate fruitfully with each other and with representatives of other functional units of HEI. TTO should become a reliable friend and assistant for HEl's innovators and senior management, as well as a partner for business and government. 
Given the established structure in HEI, at the first stage TTO will occupy the PM level in the organizational structure of $\mathrm{HEI}$ - fig. 3. However, if the performance of TTO is high and TTO demonstrates its effectiveness, it is possible to increase TTO to the operational or even strategic level in the organizational structure of $\mathrm{HEI}$.

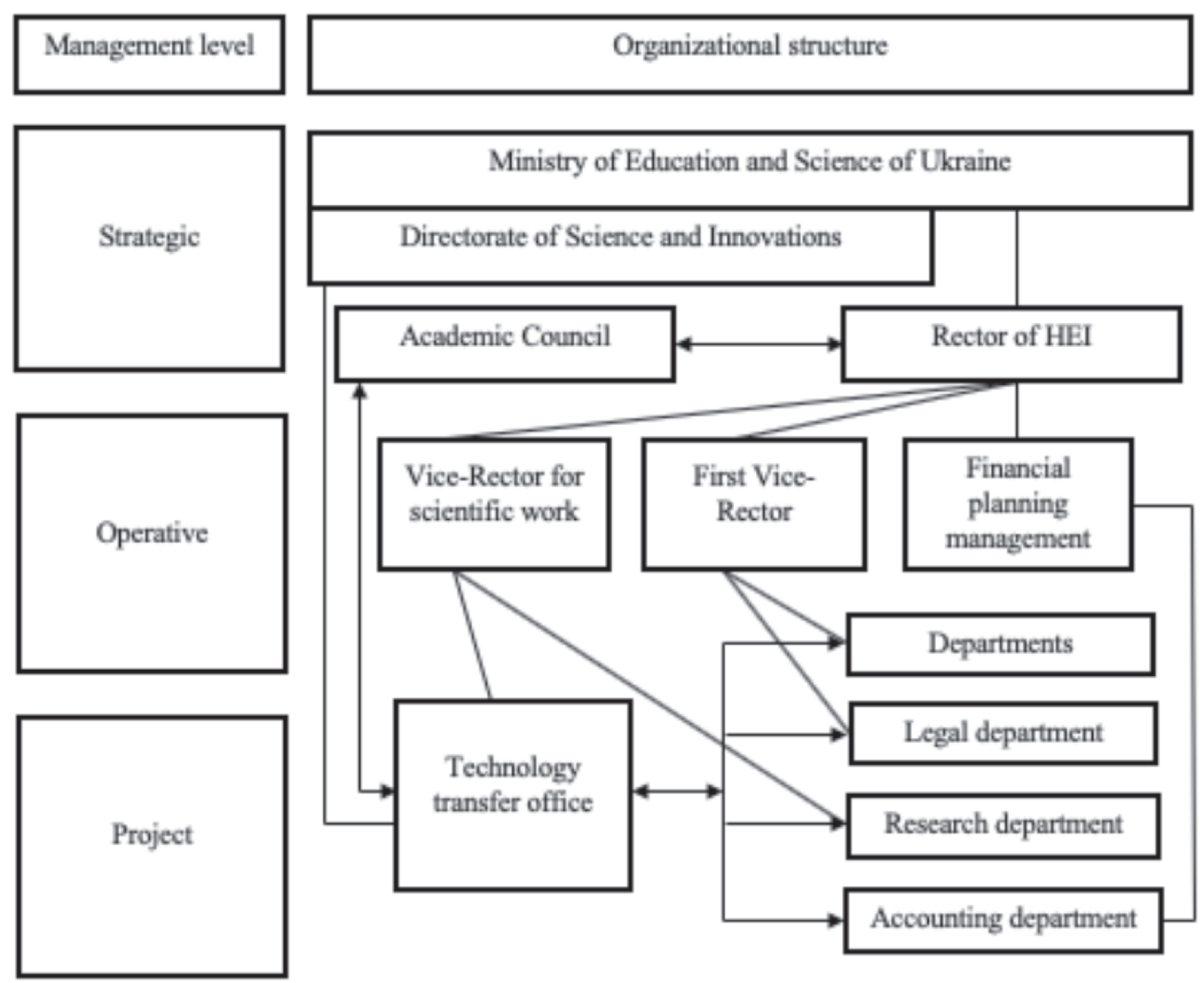

Fig. 3. A place of TTO in the organizational structure of HEI

In figure 3 lines mean subordination, arrows - information exchange and interaction. In its activities, TTO closely cooperates on the one hand with the management of the HEI and the relevant directorate of the Ministry of Education and Science, and on the other hand with innovators and potential developers of new technologies in HEI who are employees of functional units. In fact, TTO is a bond between $\mathrm{HEI}$, the state and business representatives, implementing the triple helix model.

\section{Conclusion}

In the course of the study on the creation of TTO in HEl, the authors proposed a template OBS, which will allow to organize a project team in HEl that will implement the project of creating TTO. The functions of each team member and the requirements that he/she should meet are defined. Also, in this article the authors propose a template organizational structure of TTO with the definition of the main functions of employees of this TTO and the requirements that determine the applicant's compliance with TTO in the relevant position. In addition, the place of TTO in the organizational structure of HEl, its subordination and relations with other functional units of HEI were determined. Thus, based on the models proposed in the article, any HEI will be able to create TTO. The initiated research could be a basis for further research in the field of creating TTO in HEl. 


\section{References}

1. Korogod, N.P., \& Tymchenko, D.O. (2019). Technology transfer in the management of innovative projects. Materials of the XV International Scientific and Practical Conference "Project Management: Status and Prospects". Mykolaiv, 75-76.

2. Tymchenko, D.O. (2020). Problems of creating an innovative ecosystem in Ukraine. Bulletin of NTU» KhPl». Series: Strategic management, portfolio, program and project management, vol. 2, DOI: 10.20998/2413-3000.2020.2.8.

3. Novorodovska, T.S., Korogod, N.P., \& Tymchenko, D.O. (2020). American experience of establishing technology transfer and its implementation in Ukraine. Naukovyi Visnyk Natsionalnoho Hirnychoho Universytetu, vol. 3, https://doi.org/10.33271/nvngu/2020-3/109.

4. Zagrisheva, N. V. (2017). Economic agreement on technology transfer. Dissertation for the obtaining of the degree of the candidate of legal sciences in specialty 12.00 .04 - commercial law, commercial procedural law, http://dspace.puet.edu.ua/bitstream.

5. Yehorov, S.O., Diatchyk, D.I., \& Pokshevnytska, T.V. (2015). Technology transfer office at the university. Problems and prospects for the development of innovation in Ukraine: VIII International business forum, https ://knute.edu.ua/file /MTc=/1e8a62d3ca6647b 78fd23992ec0 eb32d.pdf.

6. Project Management Body of Knowledge (PMBOK Guide). Project Management Institute. Sixth Edition (2017), 726.

7. Bushuyev, S.D. (2009). P2M: Guide to managing innovative projects and programs of enterprises. Japanese Project Management Association (PMAJ). Translation, ed. K.: Nauk. Svit, 155.

8. Individual Competence Baseline for Project (2015). Programme \& Portfolio Management. International Project Management Association (IPMA) Global Standart, Version 4.0, 431.

9. Bushuyev, S.D., Bushuyeva, N.S., \& Shorop, D.I. (2004). Project office as a methodology of multi-project management. Project management and production development: Zb.nauk.pr. Luhansk. Published by SNU. V. Dalya, https://cyberleninka.ru/article/n/proektniy-ofis-yak-metodologiya-multiproektnogo-upravlinnya/viewer.

10. Morozov, V.V., \& Chernenko, Yu.V. (2012). Conceptual model of organizational management system in the implementation of the strategy of innovative development of project-oriented organizations. IX International Conference «Project Management in Society Development. Management of programs and projects in the global financial crisis, 156-157.

11. Kendall, I., \& Rollins, K. (2004). Modern Methods for Project Portfolio Management and Project Management Office: Maximizing ROl', Trans. from English, Moscow, ZAO “PMSOFT" 338.

12. Trukhanovsky, O.M. (2012). Organization of a project management office in order to increase the effectiveness of innovation and investment projects, Abstract. diss. for the degree of candidate of economic sciences, specialty - 08.00.05 - Economics and National Economy Management. Moscow: FSBEI HPE "STATE UNIVERSITY OF MANAGEMENT", https://guu.ru/files/referate/truhanovsky.pdf, 29.

13. Tymchenko, D. (2020). Modern approaches to project management creation of project offices in higher education institutions. Management of Development of Complex Systems, issue 42, 28-38.

14. Ytskovyts, G. (2011). Triple helix model, Trans. Pavlova, I.A., Innovations, 4, 5-10, https://cyberleninka.ru/article/n/model-troynoy-spirali. 